\title{
IMPLEMENTASI MODEL VIEW CONTROLLER (MVC) PADA PENGEMBANGAN SISTEM INFORMASI PENGADUAN MASYARAKAT PADA POLRES PAGARALAM
}

\author{
Ahmad Syazili ${ }^{1}$, Irman Effendy ${ }^{* 2}$ \\ ${ }^{1}$ Program Studi Teknik Informatika, Universitas Bina Darma \\ ${ }^{2}$ Program Studi Sistem Informasi, Universitas Bina Darma \\ Jl. A. Yani No 3 Seberang Ulu I Palembang - Indonesia 30264 \\ Telp. (0711) 515582 \\ e-mail : syazili@binadarma.ac.id ${ }^{1}$,irman.effendy@binadarma.ac.id ${ }^{2}$
}

\begin{abstract}
The process of reporting a criminal offense to the Pagaralam Police Public Relations Division is considered ineffective because the reporter must go to the office directly to report a criminal complaint, which results in the accumulation of files and a long queue. This condition will certainly take time and can be interpreted as ineffective. For this reason, this study carried out the development of an information system for public complaints to the Pagaralam Police. To produce a good information system, the waterfall development process and the View Controller Model (MVC) programming technique are used. The result of this research is that the information system has two types of users, namely the reporter and the admin. The resulting information system is also capable of displaying reporting as seen from the illustration of the use of information systems. In addition, the information system can process, record, display and report data on public complaints..
\end{abstract}

Keywords-System, Information, Model View Controller

\begin{abstract}
ABSTRAK
Proses pengaduan tindak pidana kepada kepolisian Divisi Humas Polri Pagaralam dinilai kurang efektif karena pelapor harus mendatangi kantor secara langsung untuk melakukan laporan pengaduan tindak pidana, yang mengakibatkan terjadinya penumpukkan berkas serta mengalami antrian yang cukup panjang. Kondisi tersebut tentunya akan membutuhkan waktu dan dapat diartikan tidak efektif. Untuk itu pada penelitian ini dilakukan pengembangan sistem informasi pengaduan masyarakat kepada pihak Polres Pagaralam. Untuk menghasilkan sistem informasi yang baik maka digunakan proses pengembangan waterfall dan teknik pemrograman model view controller (MVC). Hasil dari penelitian ini berupa sistem informasi yang memiliki dua jenis pengguna yaitu pelapor dan admin. Sistem informasi yang dihasilkan juga mampu menampilkan pelaporan yang terlihat dari ilustrasi penggunaan sistem informasi. Selain itu istem informasi dapat memproses, mencatat, menampilkan dan melaporkan data pengaduan masyarakat.
\end{abstract}

Kata Kunci-Sistem, Informasi, Model View Controller 


\section{Pendahuluan}

Saat ini perkembangan teknologi dan komunikasi sudah berkembang pesat, sehingga dapat membuat aktivitas kegiatan menjadi lebih cepat, praktis, mudah dan menghasilkan informasi yang berkualitas. Perkembangan teknologi dan sumber informasi dari seluruh media, ternyata media internet untuk saat ini sangat digemari oleh masyarakat. Informasi yang didapat selain cepat juga dapat digunakan dan diperoleh dimana saja. Ini membuktikan bahwa masyarakat semakin tidak mau disibukkan dengan keterbatasan waktu dan kesempatan untuk melihat informasi. Internet dan web (halaman informasi) adalah salah satu contoh teknologi informasi yang banyak memberikan fasilitas dan kemudahan dalam menyelesaikan pekerjaan. Internet dapat membantu mendapatkan informasi dan dapat memberikan informasi dengan cepat dan murah [1]. Hal ini membawa pengaruh yang signifikan terhadap kebiasaan seseorang maupun organisasi, karena dengan teknologi internet efektifitas dan efesiensi waktu, tenaga dan dana dapat ditekan semaksimal mungkin. Dalam kesiapan menghadapi era keterbukaan informasi publik, Polri sebagai salah satu badan publik dituntut untuk lebih meningkatkan kinerjanya secara optimal dan professional sehingga diharapkan dapat memberikan pelayanan kepada masyrakat [2].

Pada saat ini masyarakat dalam melakukan proses pengaduan tindak pidana kepada kepolisian masih harus datang ke kantor polisi Pagaralam untuk menyampaikan pengaduan. Sesampainya masyarakat langsung menuju ke Sentra Pelayanan Kepolisian Terpadu (SPKT) untuk menyampaikan pengaduan dan apabila banyak masyarakat/pelapor yang sedang melakukan proses pengaduan maka masyarakat atau pelapor harus mengantri terlebih dahulu. Laporan pengaduan oleh pelapor dilakukan secara lisan atau tertulis. Setelah itu pihak kepolisian akan membuatkan laporan tentang tindak pidana yang masyarakat/pelapor ajukan dan selanjutnya pelapor akan terima surat tanda terima laporan. Kemudian laporan pengaduan yang masyarakat/pelapor ajukan akan diteruskan ke satuan reskrim untuk menindak lanjuti laporan tersebut. Dalam jangka waktu tertentu maka pihak pelapor akan di panggil di suruh datang lagi kekantor polisi untuk dimintai keterangan sebagai saksi korban. Hal ini akan memakan waktu cukup lama atau bisa dikatakan penggunaan waktu tidak efisien.

Hal inilah yang menjadi dorongan bagi peneliti untuk melakukan pengembangan sistem informasi pengaduan masyarakat 
oada Polres Pagaralam, dimana pembuatan ini ditujukan untuk pelayanan pengaduan masyarakat kepada Divisi Humas Polri Pagaralam. Dengan harapan masyarakat nantinya dapat mengisi langsung form pengaduan dan dapat melihat langsung jawaban dari pengaduan yang masyarakat laporkan.

Pada penelitian ini menggunakan teknik pemrograman arstektur MVC (Model View Control). MVC merupakan sebuah pendekatan perangkat lunak yang memisahkan aplikasi logika dari presentasi dengan meminimalkan script dari halaman-halaman web sejak script presentasi dipisahkan dari PHP scripting [3], mengharapkan pemrograman secara disiplin untuk membagi program menjadi 3 bagian yaitu model, view dan controller. Dengan menggunakan arstektur MVC diharapkan dapat mempercepat dan mempermudah dalam membangun Sistem Informasi Pelayanan pengaduan masyarakat kepada Divisi Humas Polri Pagaralam. Selain itu proses maintenance memiliki pola tertentu dalam sebuah framework karena Model View Control menyediakan sekumpulan library yang banyak diperlukan untuk menyelesaikan pekerjaan yang umum, dengan menggunakan antarmuka dan struktur logika yang sederhana untuk mengakses library-nya [4].

\section{Metode Penelitian}

Untuk melakukan penelitian implementasi model view controller (MVC) dalam pengembangan sistem informasi pengaduan masyarakat pada polres pagaralam maka metode metode yang digunakan dapat diejlaskan sebagai berikut:

\subsection{Metode Penelitian}

Metode yang digunakan oleh penulis adalah metode deskriptif atau dikenal dengan metode yang mengdepankan fakta dan kejadian. Penelitian deskriptif mempelajari masalah-masalah dalam objekt, baik itu menyangkut tata cara, situasi hubungan, sikap perilaku, cara pandang dan pengaruh-pengaruh dalam suatu objek [5].

\subsection{Metode Pengumpulan Data}

Dalam hal ini, teknik pengumpulan data yang penulis gunakan dalam penelitian ini yaitu:

a. Observasi (Pengamatan langsung), Dalam hal ini, penulis melakukan pengamatan secara langsung kepada objek penelitian tentang pelaksanaan dari kegiatan pelayanan pengaduan masyarakat pada Divisi Humas Polri Pagaralam dan meminta data-data yang berhubungan dengan penelitian yang penulis lakukan. 
b. Interview (Wawancara), Metode ini dilakukan dengan cara melakukan diskusi serta tanya jawab pada staf Divisi Humas Polri Pagaralam mengenai data pengaduan masyarakata, serta data-data yang diperlukan untuk penelitian.

c. Studi Kepustakaan, Metode yang dilakukan dengan mencari bahan yang mendukung dalam mendefinisikan masalah melalui buku-buku, informasi dari internet,dan bahan-bahan yang erat kaitannya dengan objek penelitian.

\subsection{Metode Pengembangan}

Dalam hal ini, metode pengembangan sistem yang penulis gunakan adalah metode waterfall adalah suatu metedologi pengembangan perangkat lunak yang yang mengusulkan pendekatan perangkat lunak sistematik dan sekuensial yang mulai pada tingkat keamjuan sistem pada seluruh analisis, design, kode, pengujian dan pemeliharaan [6]. Langkah-langkah yang harus dilakukan pada metedologi waterfall adalah sebagai berikut:

\section{Requirements Definition, Proses} pengumpulan kebutuhan dilakukan secara intensif mungkin demi untuk menspesifikasikan kebutuhan sebuah sistem infformasi yang diingkan oleh pengguna [7]. Kebutuhan sistem informasi dapat dibuat dalam bentuk aliran sistem informasi.

2. System and Software Design, Pada design proses ini akan dialokasikan hardware dan software berdasarkan pernyataan yang telah ditetapkan [8]. Dan juga mengidentifikasi dan menggambarkan abtraksi dasar sistem perangkat lunak dan hubunganhubungannya. Tahap ini lah yang mentraslasi kebutuhan perangkat lunak, dari tahap analisis kebutuhan ke reperentasi kebutuhan perangkat lunak, dari tahap analisis kebutuhan ke reperentasi desain agar kelak di implementasikan menjadi sebuah program pada tahap selanjutnya. Design Software yang dihasilkan pada tahap ini juga perlu kiranya untuk didokumentasikan.

3. Implementation and Unit Testing, Dalam tahapan ini, design harus ditranslasikan kedalam program perangkat lunak. Kemudian hasil dari tahapan ini adalah sebuah program computer yang sesuai dengan design yang telah dibuat pada tahap sebelumnya [9].

4. Integration and System Testing, Dalam tahapan ini, pengujian terfokus pada software secara logis dan fungsional serta harus dipastikan bahwa semua bagian telah diuji, Hal 
ini dilakukan demi untuk mengurangi kesalahan (error) dan memastikan output yang dihasilkan sesuai dengan yang diinginkan [10].

5. Operatation and Maintenance, tapahapan ini merupakan tahapan akhir dari proses pengembangan. dimana sistem informasi telah dapat digunakan dan dilakukan perawatan jika terdapat kendala pengeoperasiannya.

\section{Hasil DAN PEMBahasan}

Sesuai dengan proses penelitian dan metode yang digunakan dalam peneltian maka hasil penelitian yang dihasilkan berupa sistem informasi pelaporan pengaduan masyarakat pada Polres Pagaralam dengan menerapkan konsep model view controller (MVC). Implementasi konsep model view controller $(M V C)$ dilakukan menggunakan framework CodeIgniter (CI). Secara menyeluruh alur dari proses pelaporan tersebut seperti yang diperliatkan pada Gambar 1.

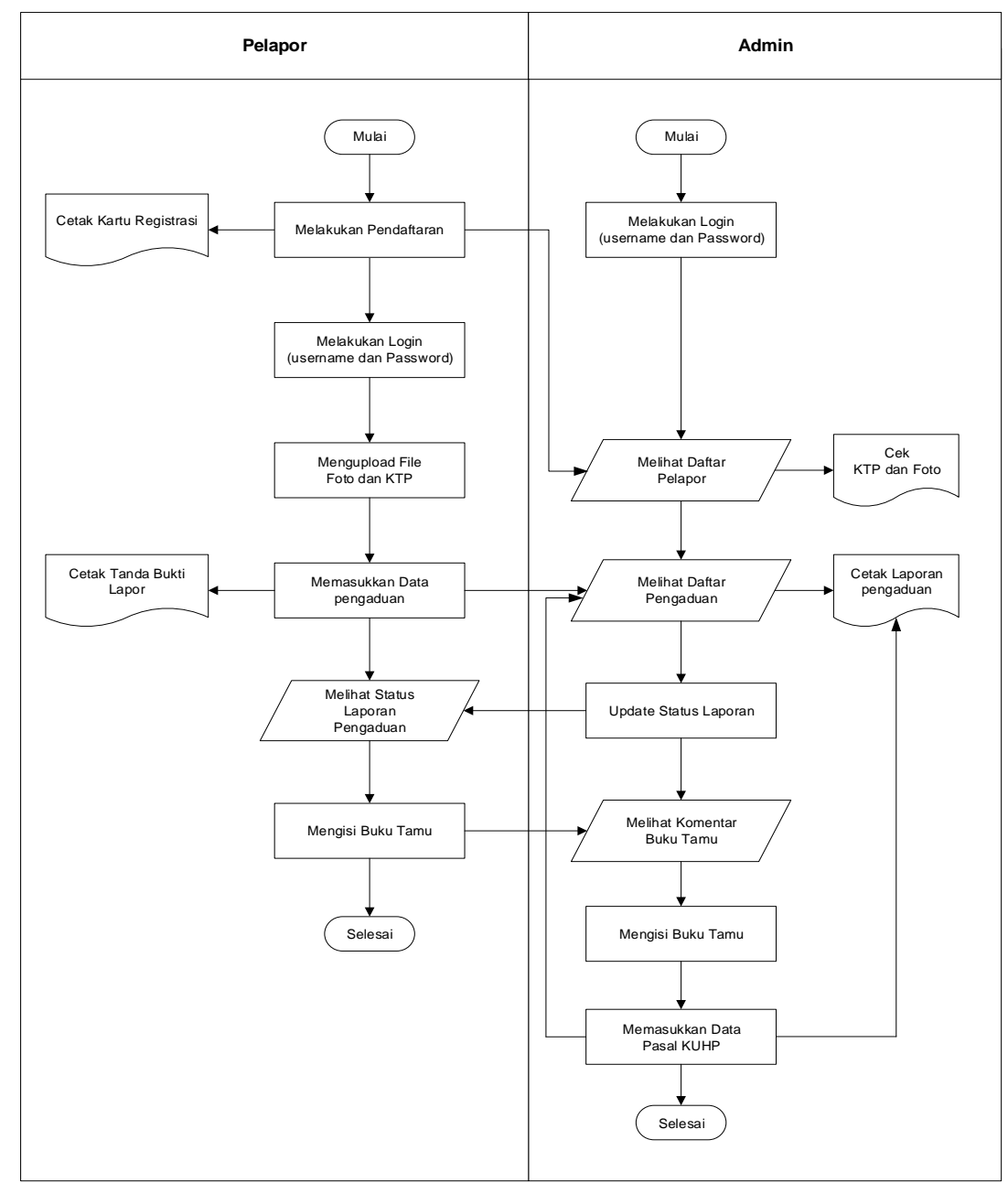

Gambar 1. Flowchart Sistem Informasi 
Sesuai dengan Gambar 1 maka dapat diketahui bahwa terdapat dua jenis pengguna dari sistem informasi pelaporan pengaduan yaitu pelapor dan admin dari sistem informasi. pelapor dapat melakukan berbagai hal seperti melengkapi data diri sebagai pelapor, melakukan laporan dan melihat proses atau kemajuan dari laporan. Sedangkan admin dapat melihat laporan masuk serta melakukan perubahan status pelaporan. Gambar 2 merupakan tampilan utama dari sistem informasi pelaporan pengaduan.

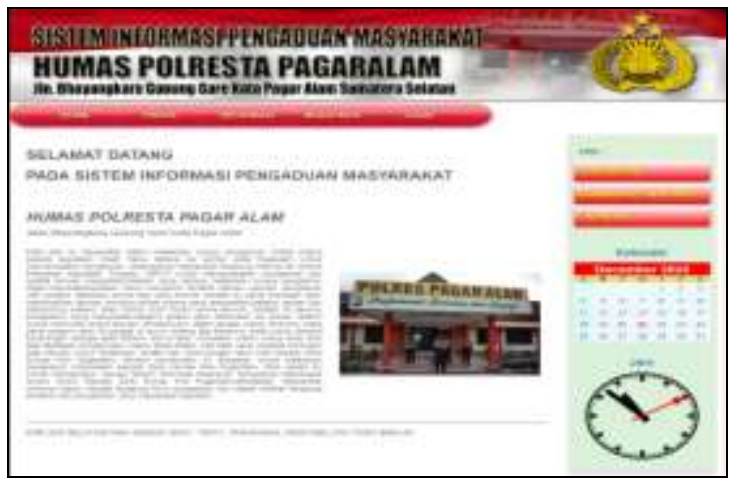

Gambar 2. Utama Sistem Informasi

Selain itu juga pada halaman utama juga terdapat informasi yang berkaitan dengan kejadian dan atau berita yang dapat dilihat oleh pengunjung baik itu masyarakat atau mereka yang ingin melakukan pelaporan. Pada halaman utama juga dapat dilihat informasi tata cara penggunaan sistem informasi pelaporan pengaduan seperti yang diperlihatkan pada Gambar 3.

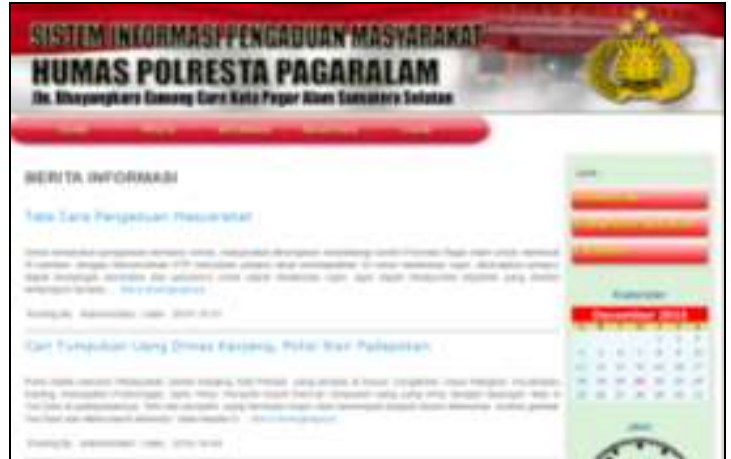

Gambar 3. Informasi bagi masyarakat

Untuk melakukan pelaporan maka masyarakat harus melakukan registrasi sebagai pelapor dengan cara mengklik menu register. Selanjutnya masyarakat diminta untuk melakukan pengisian data pribadi sebagai bentu validasi dan menjamin kebenaran dari laporan yang diberikan oleh masyarakat. Gambar 4 merupakan tampilan dari proses registrasi yang dapat dilakukan oleh masyarakat pada sistem informasi pelaporan. Data yang dimasukkan antara lain adalah nomor KTP, alamat, pekerjaan, kewarganegaraan dan juga nomor telepon.

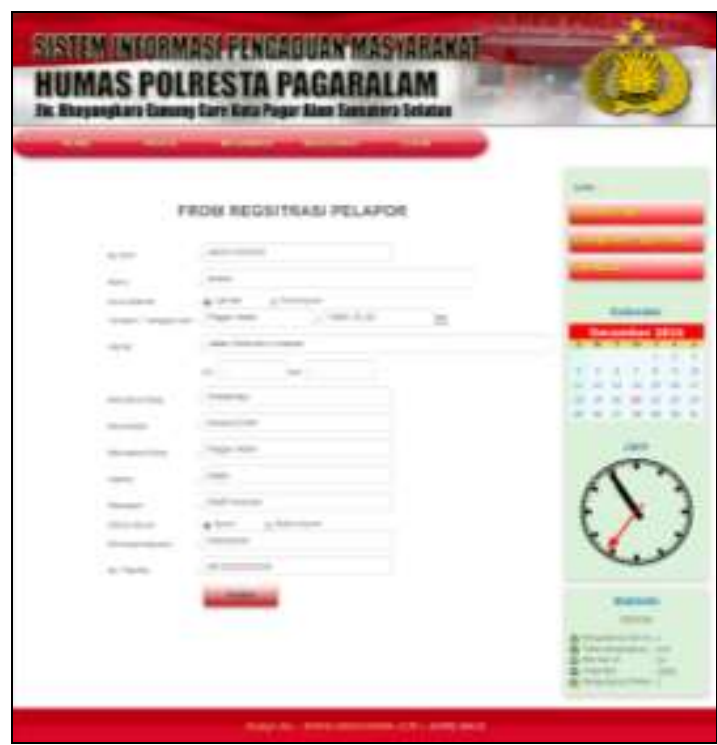

Gambar 5. Form Registrasi Pelapor 
Setelah melakukan proses registasi seperti yang diperlihatkan pada Gambar 5 maka barula pelapor atau masyarakat dapat melakukan login dan akan ditampilkan halaman khusus pelapor seperti yang diperlihatkan pada Gambar 6.

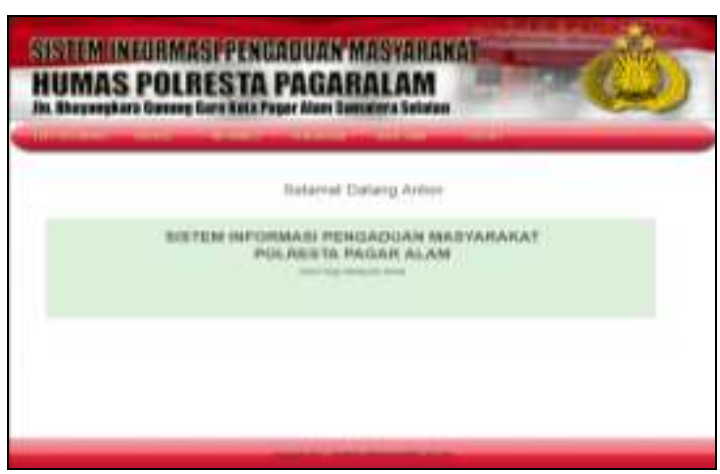

Gambar 6. Halaman Pelapor

Seperti yang diperlihatkan pada Gambar 6 maka dapat diketahui bahwa terdapat beberpa menu yang dapat diakses diantarnaya adalah menu biodata pelapor, informasi, pengaduan, buku tamu dan logout. Untuk melakukan pengaduan maka pelapor dapat mengklik menu pengaduan maka akan ditampilkan informasi pengaduan seperti yang dipelihatkan pada Gambar 7.

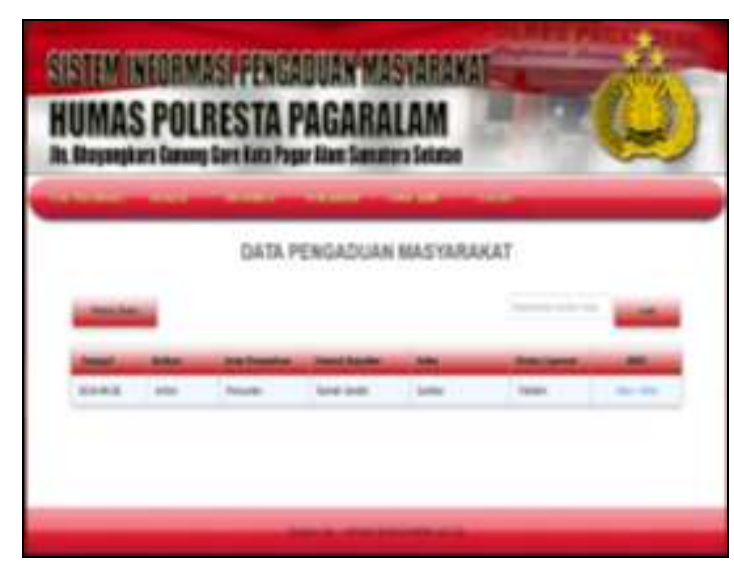

Gambar 7. Informasi Pengaduan
Untuk melakukan pengaduan maka melakukan klik entry data dan akan ditampilkan form entry data pengaduan seperti yang diperlihatkan pada Gambar 8 . Data yang dimasukkan antara lain seperti tanggal pelaporan, jenis pengaduan, tempat kejadian, korban, kronologis kejadian, barang bukti, saksi, nomor KTP saksi, alamat saksi dan nomor telepon saksi.

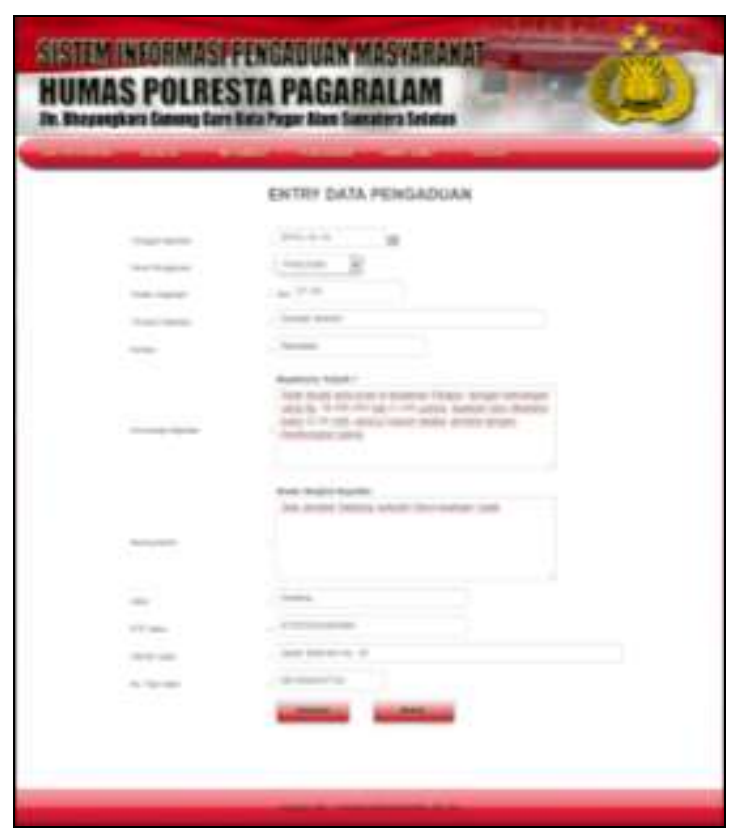

Gambar 8. Form Pengaduan

Setelah proses pengaduan yang dilakukan oleh masyarakat atau pelapor maka selanjutnya laporan tersebut dapat dilihat oleh admin dari sistem informasi. untuk melihat pengaduan yang masuk maka dapat dilihat dari menu pengaduan dan akan ditampilkan daftar pengaduan yang ada seperti yang diperlihatkan pada Gambar 9. 


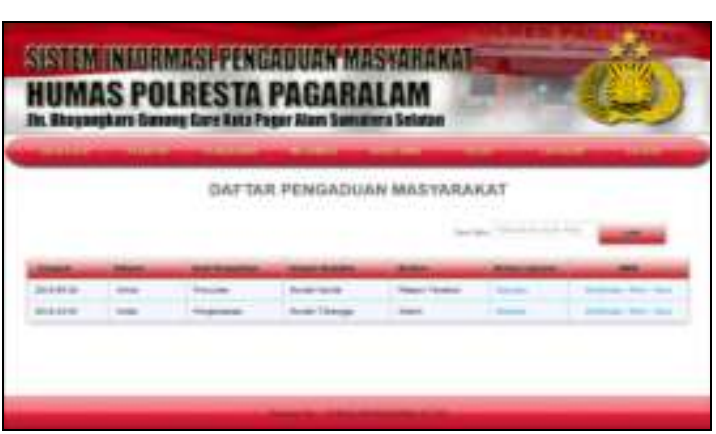

Gambar 9. Daftar Pengaduan

Untuk melihat detail paleporan maka dapat dilihat dari link view sedangkan untuk menerima laporan dapat dilakukan denan klik konfirmasi. Detail laporan masuk seperti pada Gambar 10.

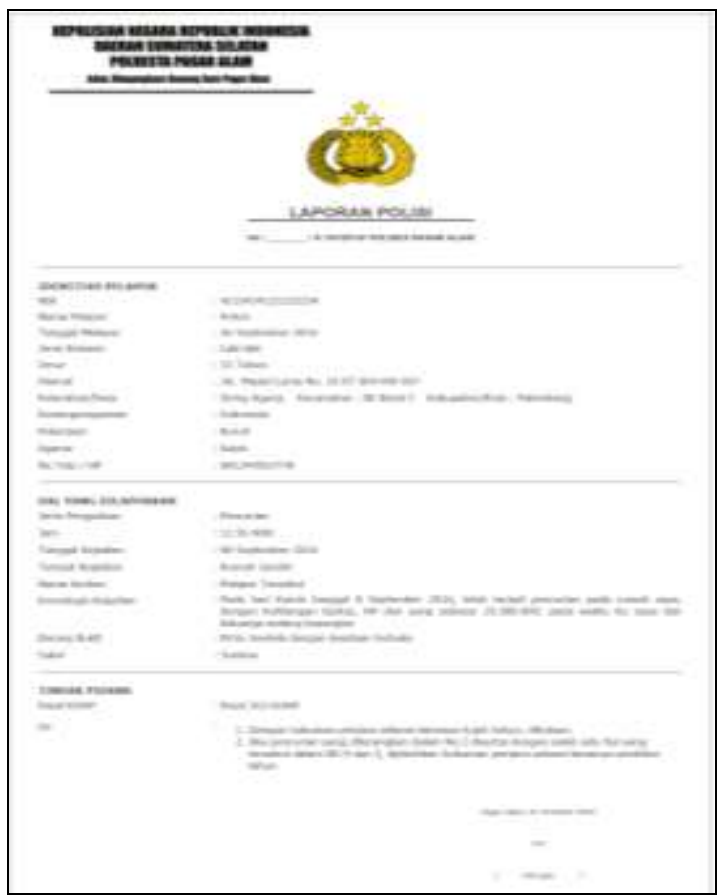

Gambar 10. Detail Laporan Masuk

Selain melihat informasi laporan pengaduan masyarakat admin juga dapat mencetak laporan masuk yang diberikan oleh masyarakat. Laporan tersebut dapat dicetak seperti yang diperlihatkan pada Gambar 11.

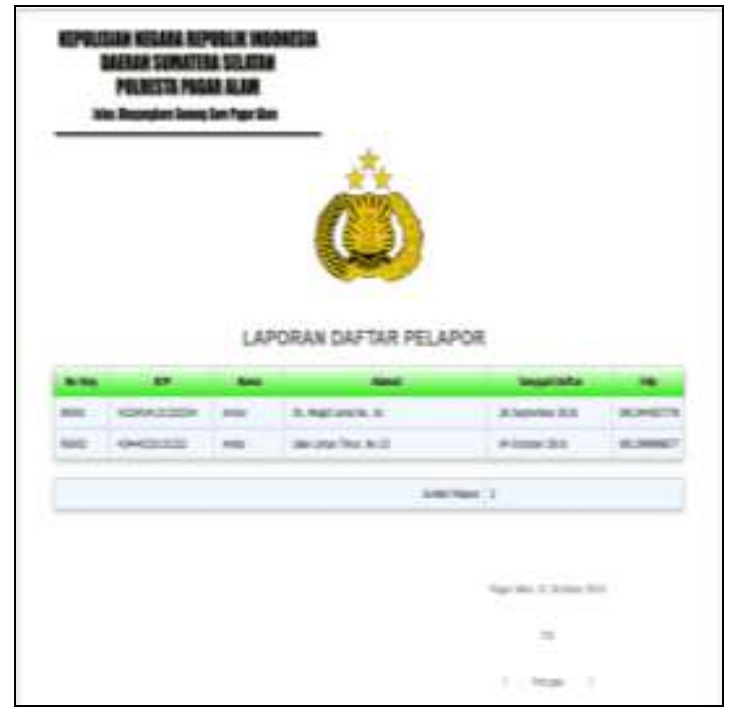

Gambar 10. Laporan Data Pengaduan

Dari semua bentuk sistem informasi yang dihasikan seperti yang diperlihatkan pada Gambar 2 sampai dengan Gambar 10 maka proses pembentukan sistem infromasi dilakukan menggunakan model view controller (MVC) dengan menerapkan framework CodeIgniter (CI). Untuk itu salah satu proses pembentukan tersebut seperti yang diplerlihatkan pada Gambar 11.

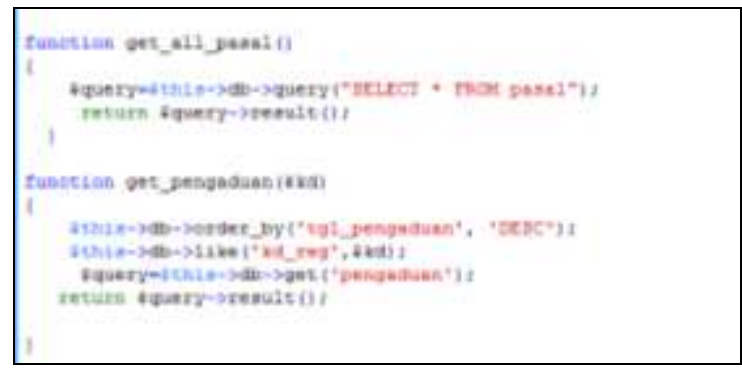

Gambar 11. Kode Model dalam MVC

Gambar 11 merupakan kode untuk model, model merupakan kode yang digunakan untuk mengakses data pada database sistem informasi. Sedangkan untuk menampilkan informasi pada pengguna dilakukan oleh view. Gambar 11 
merupakan salah satu kode dari view pada MVC.

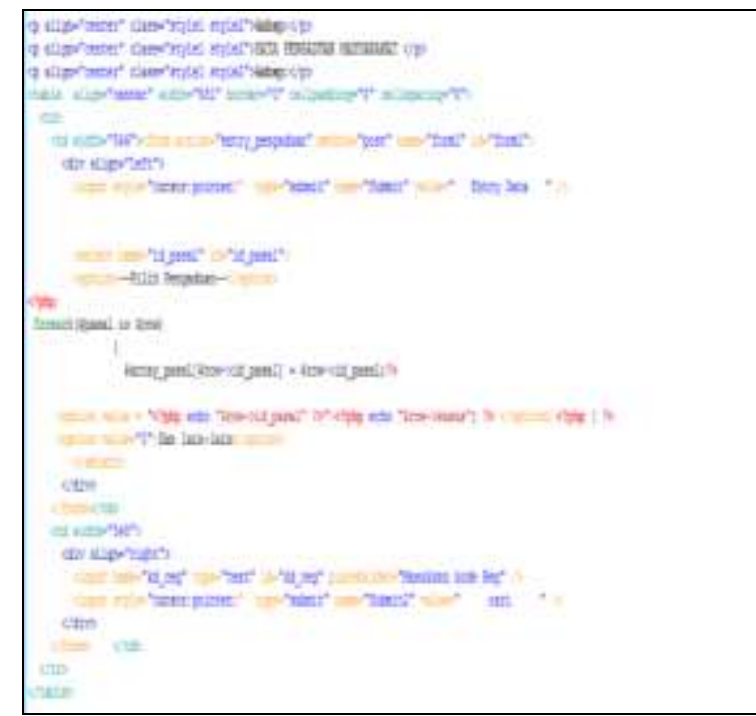

Gambar 12. Kode View dalam MVC

Untuk mengatur bagaimana pengaksesan dan pendistribusian informasi dan menu pada sistem informasi pelaporan pengaduan maka dilakukan oleh controller. Gambar 13 dapat dilihat merupakan salah satu kode controller dalam MVC dengan menggunakan framework CodeIgniter (CI).

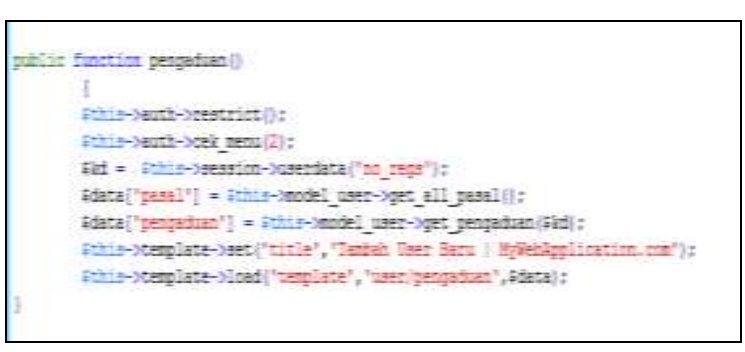

Gambar 13. Kode Controller dalam MVC

\section{Simpulan}

Berdasarkan hasil penelitian yang telah dibahas sebelumnya maka dapat disimpulkan bahwa (1) pengembangan sistem informasi pengaduan masyarakat telah dilakukan dengan menggunakan teknik model view controller (MVC) dan metode pengembangan waterfall. sistem informasi yang dihasilkan memiliki dua jenis pengguna yaitu pelapor dan admin. (3) sistem informasi yang dihasilkan mampu untuk memproses pelaporan yang dibuktikan dari ilustrasi penggunaan sistem informasi. (4) sistem informasi juga dapat memproses, mencatat, menampilkan dan melaporkan data pengaduan masyarakat.

\section{UCAPAN TERIMA KASIH}

Terima kasih penulis sampaikan kepada tim Jurnal Informatika IBI Darmajaya yang telah memberikan kesempatan kepada kami penulis untuk mempublikasikan artikel ini. Selain itu juga kami sampaikan banyak terima kasih kepada reviewer yang telah memberikan waktunya dalam melakukan review artikel ini sehingga kami penulis mendapatkan masukkan.

\section{DAFTAR PUSTAKA}

[1] D. Setiawan, "Dampak perkembangan teknologi informasi dan komunikasi terhadap budaya," J. SIMBOLIKA Res. Learn. Commun. Study, vol. 4, no. 1, pp. 62-72, 2018.

[2] F. Masya and F. M. Simanjuntak, 
"Sistem pelayanan pengaduan masyarakat pada divisi humas polri berbasis web," in Seminar Nasional Aplikasi Teknologi Informasi (SNATI), 2012.

[3] A. Komarudin, "Pembangunan Website Dan Repositori Pada Sistem Penjamin Mutu (SPM) Universitas Jenderal Achmad Yani," J. Muara Sains, Teknol. Kedokt. dan Ilmu Kesehat., vol. 1, no. 1, pp. 164-174, 2017.

[4] P. Maulana, "APLIKASI PENJUALAN BERBASIS WEB PADA CV. JAYA SAKTI ELEKTRONIC." Universitas Widyatama, 2017.

[5] S. Sauda and E. P. Agustini, "Implementasi Prototype Model dalam Pengembangan Aplikasi Smart Cleaning Sebagai Pendukung Aplikasi Smart City," MATRIK J. Manajemen, Tek. Inform. dan Rekayasa Komput., vol. 20, no. 1, pp. 73-84, 2020.

[6] C. Tristianto, "Penggunaan metode waterfall untuk pengembangan sistem monitoring dan evaluasi pembangunan pedesaan," in ESIT, 2018, vol. 12, no. 1, pp. 8-22.

[7] D. Driyani, "Perancangan Media Pembelajaran Sekolah Dasar Berbasis Android Menggunakan
Metode Rekayasa Perangkat Lunak Air Terjun (Waterfall)," STRING (Satuan Tulisan Ris. dan Inov. Teknol., vol. 3, no. 1, pp. 35-43, 2018

[8] S. R. Wurdianarto, S. Novianto, and U. Rosyidah, "Perbandingan euclidean distance dengan canberra distance pada face recognition," Techno. Com, vol. 13, no. 1, pp. 31-37, 2014.

[9] N. Indriani, "Pengembangan Simulasi 'Stress Test' Menggunakan Tes Kraepelin pada Tes Psikologi,” 2019.

[10] D. I. Permatasari et al., "Pengukuran throughput load testing menggunakan test case sampling gorilla testing," in Seminar Nasional Sistem Informasi (SENASIF), 2019, vol. 3, no. 1, pp. 2008-2014. 